\title{
IMPROVEMENT OF WEEDS MANAGEMENT SYSTEM AND FERTILISERS APPLICATION IN WINTER WHEAT (TRITICUM AESTIVUM L.) CULTIVATION TECHNOLOGIES
}

\author{
NAZIH YACER REBOUH ${ }^{1, *}$, MORAD LATATI ${ }^{2}$, PETER POLITYKO ${ }^{3}$, ZARGAR MEISAM ${ }^{1}$, \\ NYASHA JOHN KAVHIZA ${ }^{1}$, NINA GARMASCH ${ }^{3}$, ELENA PAKINA ${ }^{1}$, MARINA LYSHKO ${ }^{1}$, \\ ALBERT ENGERIBO ${ }^{1}$, ELCHIN ORUJOV ${ }^{1}$ AND VALENTIN VVEDENSKIY $^{1}$
}

\author{
${ }^{1}$ Peoples Friendship University of Russia (RUDN University), Moscow, Russian Federation \\ ${ }^{2}$ Laboratoire d'Amélioration Intégrative des Productions Végétales, Algiers, Algeria \\ ${ }^{3}$ GNU Moscow Research Institute of Agriculture "Nemchinovka", Russia
}

Rebouh, N.Y., Latati, M., Polityko, P., Meisam, Z., Kavhiza, N.J., Garmasch, N., Pakina, E., Lyshko, M., Engeribo, A., Orujov, E. and Vvedenskiy, V. (2021). Improvement of weeds management system and fertilisers application in winter wheat (Triticum aestivum L.) cultivation technologies. Agriculture (Pol’nohospodárstvo), 67(2), 76-86.

\begin{abstract}
Wheat production plays a central role in the Russian agricultural system and significant land area is dedicated to this strategic crop. However, the wheat enterprise is highly constrained by weed interference which cause serious yield losses hence minimizing production income. The main objective of the study was to assess the efficacy of three various cultivation technologies as basic, intensive, and highly intensive systems on wheat biological efficiency. Three weed species Echinochloa crus-galli, Stellaria media, and Viola arvensis, and three winter wheat (Triticum aestivum L.) varieties Moscovskaya 40 (V1), Nemchinovskaya 17 (V2) and Nemchinovskaya 85 (V3) were studied. The data was analysed as a randomized complete block design with three replicates. Weed density, biological efficiency, yield performances, and selected qualitative parameters (measured through protein and gluten contents) were determined as affected by different cultivation technologies. The results showed that the high intensive cultivation technology (T3) was the most effective in reducing weed infestation levels as follows (0.3 plant $/ \mathrm{m}^{2}$ Echinochloa crus-galli, $0.5 \mathrm{plant} / \mathrm{m}^{2}$ Stellaria media and $0.4 \mathrm{plant} / \mathrm{m}^{2}$ Viola arvensis) with biological efficiency of $96 \%$, while $81 \%$ and $90 \%$ were recorded with basic and intensive cultivation system respectively. Moreover, the highest wheat yield $10.6 \mathrm{t} / \mathrm{ha}$ was obtained by T3, with the greatest grain quality $5 \%$ higher than basic cultivation technology designated in T1. The results were variety-dependent revealing the intrinsic genetic performances and the different patterns of high competitive ability. The current results open real opportunities concerning the implementation of potent wheat production systems.
\end{abstract}

Key words: gluten content, herbicide, proteins content, weed, wheat varieties, yield

Chemical method plays a key role in controlling weeds that infest wheat fields. Herbicides are the most effective weed control tools developed recently in all over the world, suppressing $90-99 \%$ of weeds (Talgre et al. 2008). Nevertheless, herbicide resistance particularly in major field crops (wheat, rice, maize, soybean), has become a widespread problem posing a formidable challenge for global food production systems (Beckie et al. 2000; Ibrahim et al. 2016; Pansu et al. 2018). Currently many

Rebouh Nazih Yacer, PhD. (*Corresponding author), Meisam Zargar, Kavhiza Nyasha John, PhD. student, Pakina Elena, PhD., Lyshko Marina, PhD., Engeribo Albert, Orujov Elchin, PhD. student, Vvedenskiy Valentin, Peoples Friendship University of Russia (RUDN University), 6 Miklukho-Maklaya St, Moscow, 117198, Russian Federation. E-mail: n.yacer16@outlook.fr Latati Morad, PhD., Laboratoire d'Amélioration Intégrative des Productions Végétales (C2711100), Département de Productions égétales, Ecole Nationale Supérieure Agronomique (ENSA), Avenue Hassane Badi, El Harrach, Algiers 16200, Algeria Polityko Petr, prof., Garmasch Nina, PhD., GNU Moscow Research Institute of Agriculture "Nemchinovka", Russia 
weed species are developing resistance to herbicides from different modes of action, and becoming more difficult and expensive to be controlled. Several studies in the recent years revealed that continued use of herbicides with the same mode of action (MOA) applies selection pressure on the weed population, this increases the genotype frequency of resistant individuals that eventually becomes the dominant component of the population (Mohammadi et al. 2018). As a solution, chemical management strategies such as rotating active ingredients with the different MOAs and combining (tank mix) herbicides from the various chemical families have been established to evade herbicide resistance. The selection of such herbicides should be based on biological knowledge of all dominant weed species in the field, while maintaining a balance between herbicide costs, weed thresholds, and environmental impacts (Nazarko et al. 2005; Chhokar et al. 2012).

In addition to the chemical methods, other control practices were developed to control weeds in farming systems. For example, increasing weedcrop competition, through the development of crop varieties with the high competitive ability can be illustrated. Previous studies reported that some crop genotypes had a high competitive ability against weeds (Mason et al. 2007; Fragasso et al. 2013). Hence, De Vita et al. (2017) investigated the effects of inter-row spacing as a cultural method on wheat competition against weeds. Mentioned study demonstrated that competitive ability directly depends on the wheat cultivars, thus, crop rotation was perfumed to control weed populations. It has been reported that crop rotation reduces growth, fecundity, and weed establishment by disrupting their life cycle (Nichols et al. 2015). Furthermore, it was observed that monoculture or continuous cropping within a field increases weeds density, whereas breaks in the cropping sequence with other crops often significantly diminish weeds interference (Hosseini et al. 2014).

Crop production for the purpose of human consumption such as wheat is of paramount importance worldwide (Polityko et al. 2020). Weeds are one of the major constraints causing serious losses in wheat yields and quality (Van der Meulen et al. 2017). Moreover, weed communities possess high phonological plasticity which enables them to adapt to new management techniques (Vila-Aiub et al. 2019). Almost, direct yield losses due to weed infestations are ranged $20-40 \%$ in the global wheat production (Fahad et al. 2015; Gharde et al. 2018). For mentioned reasons, cropping systems need new management strategies, including cultural practices and genetic engineering technique (development of new varieties) to suppress weed growth and spread that cause wheat yield losses. The optimization of weed management systems, therefore, is becoming indispensable in wheat production systems to ensure high yields and better grain quality.

A three year study was carried out to investigate the effectiveness of three cultivation technologies included fertilisers, herbicides, and growth regulators in different combinations and doses to control weeds in order to estimate their influence on winter wheat yield and grain quality.

\section{MATERIAL AND METHODS}

\section{Experimental site}

Experiments were conducted over three wheat growing seasons (2016-2017, 2017-2018, and 2018-2019) at the Moscow Research Institute of Agriculture "Nemchinovka", Odintsovo district,

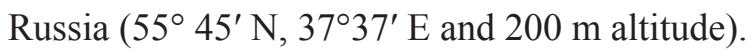

\section{Climatic conditions}

The climate in the Moscow region was mid-continental characterized by mild winter, occasional flaw, and warm damp summer. The mean annual temperature was $6.3^{\circ} \mathrm{C}$. The average temperature of the warm-season (May-October) was $13.5^{\circ} \mathrm{C}$; the average monthly temperature in January and July was $-8.40^{\circ} \mathrm{C}$ and $18.10^{\circ} \mathrm{C}$, respectively. Positive ambient temperatures are experienced for an average of 215 days. Moreover, temperatures above $10^{\circ} \mathrm{C}$ (vegetation season) occur for an average of 130 days. The average cool season (November-March) temperature was $-5.70^{\circ} \mathrm{C}$. Mean annual precipitation was $628 \mathrm{~mm}: 56 \%$ in the spring-summer season and $26 \%$ in autumn. The average precipitation rate from May to September was $339 \mathrm{~mm}$.

\section{Weed density estimation}

Weeds were investigated in three to five leaves stage of winter wheat. The dominant weed species 
during three years of the experiment were: Viola arvensis, Stellaria media and Echinochloa crus-galli. These species typically germinate in autumn and spring in the condition of Moscow region. The weed density was calculated manually before treatments and after treatments (28 days after treatments). The weed density was expressed as number of plant $/ \mathrm{m}^{2}$ in each plot according to the cultivation technology. The total area of the experimental field was $700 \mathrm{~m}^{2}$. The total area was sub-divided into three blocks; each block was further subdivided into nine plots in which the total area of each plot was $25 \mathrm{~m}^{2}$. The experiment was performed in three replications for each treatment.

\section{Experimental design and treatments}

For three years of the study, the experiments were laid out as Randomized Complete Block Design with three replications. Three cultivation technologies [basic (T1), intensive (T2) and high intensive (T3)] were examined as the main plots whilst wheat varieties [Moscovskaya 40 (V1), Nemchinovskaya 17 (V2) and Nemchinovskaya 85 (V3)] were as subplots.

A description of experimental inputs for all three cultivation technologies is presented in Table 1 . The herbicides were applied to wheat seedlings at the three-five leaves stage. The fertilisation was carried out in pre-sowing with top dressing, at the tillering and earing stages.
Sowing was done at the beginning of September with a planter (seeder SN 16 PM) at a rate of 5 million seeds/ha.

A modern combine harvester was used to harvest wheat (Polityko et al. 2020). The wheat was harvested around the mid-August at ripening stage.

The crop rotation implemented in the experimental field was as legumes, spring cereals and winter cereals. Particularly, the crop that preceded the winter wheat investigated in the study was peas.

Tillage operations were done before each growing season after harvesting the predecessor crop, with a ploughing depth of $20-22 \mathrm{~cm}$.

\section{Biological efficiency}

The biological efficiency effectuated by the cultivation technologies was calculated manually 28 days after treatment and before harvest of winter wheat. Weed density was investigated and calculated as number of plant $/ \mathrm{m}^{2}$ in each experimental plot, according to the cultivation technologies applied, using the following formula (Polityko et al. 2020):

$\mathrm{BE}[\%]=100-(\mathrm{Nbr} . \mathrm{a} \times 100 / \mathrm{Nbr} . \mathrm{b})$

BE - biological efficiency [\%]; Nbr.a - number of plant $/ \mathrm{m}^{2}$, after treatment; Nbr.b-number of plant $/ \mathrm{m}^{2}$, before treatment; 100 - conversion coefficient [\%].

$\mathrm{T}$ a b 1 e 1

Applied herbicide and fertilisers in different cultivation technologies

\begin{tabular}{|c|c|c|}
\hline Cultivation technologies & \multicolumn{1}{|c|}{ Fertilisers $[\mathrm{kg} / \mathrm{ha}]$} & \multicolumn{1}{|c|}{ Crop protection details } \\
\hline 1. Basic (T1) & $\begin{array}{l}\text { Basal application } \mathrm{N}(30), \mathrm{P}_{2} \mathrm{O}_{5}(30), \mathrm{K}_{2} \mathrm{O}(90)[\mathrm{kg} / \mathrm{ha}] \\
\text { in pre-sowing and } \mathrm{N}(30)[\mathrm{kg} / \mathrm{ha}] \text { at the tillering phase }\end{array}$ & $\bullet$ Herbicide: Lintur $180[\mathrm{~g} / \mathrm{ha}]$ \\
\hline 2. Intensive (T2) & $\begin{array}{l}\text { Basal application } \mathrm{N}(60), \mathrm{P}_{2} \mathrm{O}_{5}(60), \mathrm{K}_{2} \mathrm{O}(120)[\mathrm{kg} / \mathrm{ha}] \\
\text { in pre-sowing, Top dressing, at the tillering phase, } \\
\mathrm{N}(30)[\mathrm{kg} / \mathrm{ha}]\end{array}$ & $\begin{array}{l}|c| \text { Herbicide: Accurate Extra } 25[\mathrm{~g} / \mathrm{ha}] \\
\text { Growth regulator: Sapress } 0.3[\mathrm{~L} / \mathrm{ha}]\end{array}$ \\
\hline 3. High Intensive (T3) & $\begin{array}{l}\text { Basal application } \mathrm{N}(90), \mathrm{P}_{2} \mathrm{O}_{5}(90), \mathrm{K}_{2} \mathrm{O}(150)[\mathrm{kg} / \mathrm{ha}] \\
\text { in pre-sowing, Top dressing, at the tillering and } \\
\text { earing phases, } \mathrm{N}(30) \text { and } \mathrm{N}(30)[\mathrm{kg} / \mathrm{ha}], \text { respectively }\end{array}$ & $\begin{array}{l}\text { Tandem } 25[\mathrm{~g} / \mathrm{ha}] \\
\text { Growth regulator: Sapress } 0.3[\mathrm{~L} / \mathrm{ha}]\end{array}$ \\
\hline
\end{tabular}


Determination of protein and gluten content

Selected qualitative parameters (determined via protein and gluten content) were measured for all winter wheat varieties.

The percentage of protein content was analysed by calculating the total nitrogen concentration in grain using the Kjeldahl method (Kjeldahl 1883), the following formula was used:

Protein $[\%]=[(\mathrm{N} \times 100) /(100-\mathrm{W})] \times \mathrm{K}$

$\mathrm{N}$ - the nitrogen content in the grain [\%]; $\mathrm{W}$ - the moisture content of the grain or its processed products [\%]; K - conversion coefficient of nitrogen content to protein, equal to: 5.7 for wheat.

The gluten content in wheat grain was calculated by hand washing method (Polityko et al. 2020). The amount of raw or dry gluten in the grain \%, calculated to the first decimal place, for dry-to the second decimal place by the following formula:

Gluten $[\%]=\mathrm{MG} / \mathrm{Mg} \times 100$

$\mathrm{MG}$ - the number of raw or dry gluten $[\mathrm{g}] ; \mathrm{Mg}-$ the number of the sample of ground grain $[\mathrm{g}]$; 100 - conversion coefficient [\%].

\section{Statistical analysis}

Data analysis was performed using Statview 4.02 software (Abacus Concepts Inc., Berkeley, CA, USA). Values for each variable were expressed as the mean \pm SEM (Standard Error of Mean). Variables used for comparison purposes were the three weed species abundance as influenced by the three cultivation technologies: Basic (T1), Intensive (T2), and High Intensive (T3). Differences between treatments (wheat yield, gluten content, and proteins content) were assessed using Analysis of variance (ANOVA) at a significance of $p$-value $<0.05$, and Tukey's test was used for mean comparisons in each treatment that was significant. Linear regression was used to evaluate the relationship between biological efficiency of cultivation technologies, wheat yield and grain quality.

\section{RESULTS}

\section{Weed infestation}

Figure 1 shows weed infestation of the three winter wheat species after treatments. Weed infestation levels were highest before treatment application as Echinochloa crus-galli, Stellaria media and Viola arvensis 30,18 and 16 plant $/ \mathrm{m}^{2}$, respectively. However, after treatment, a significant weed reduction

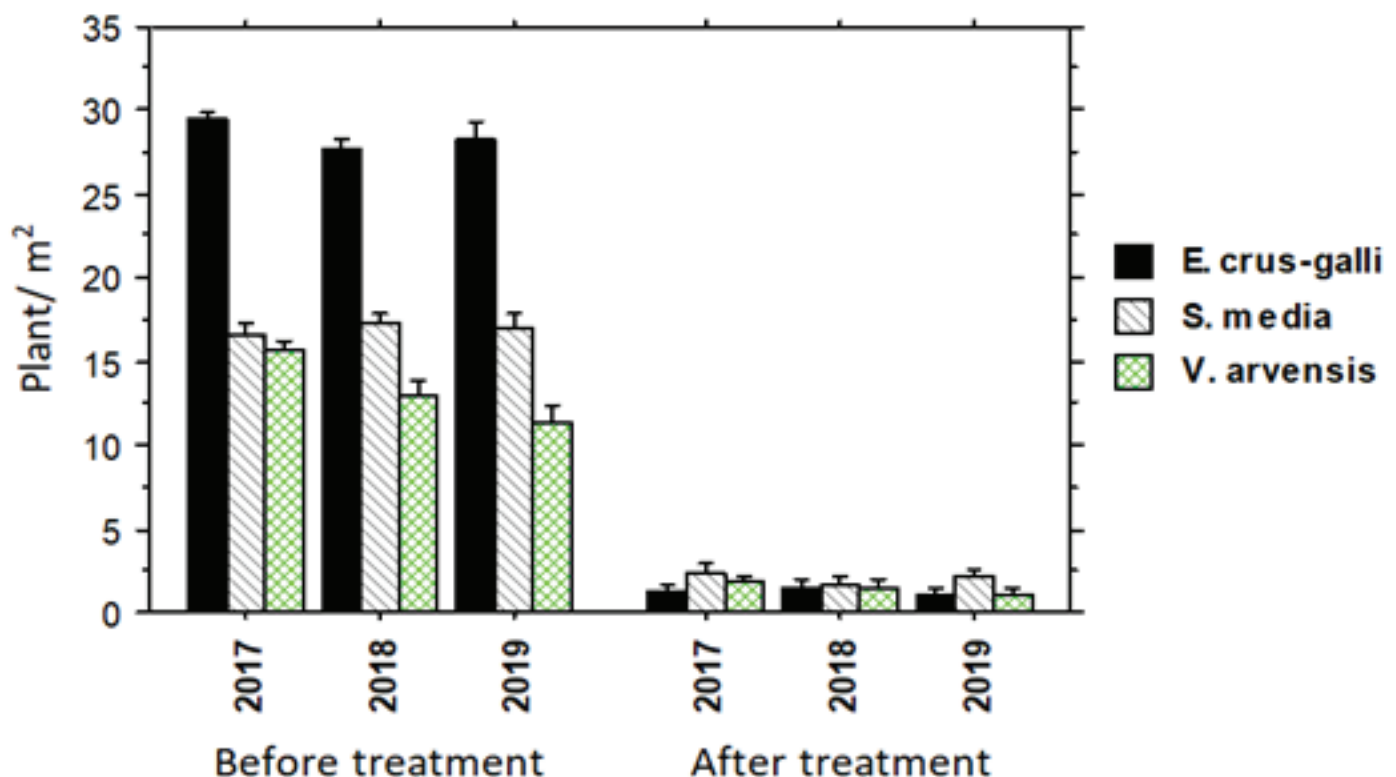

Figure 1. Influence of the cultivation technologies (T1 - basic, T2 - intensive and T3 - high intensive) on weed infestation levels of the three studied species 
$\mathrm{T}$ a

Grain yield and quality variation of each wheat varieties under different studied cultivation technology

\begin{tabular}{|c|c|c|c|c|c|}
\hline $\begin{array}{l}\text { Cultivation } \\
\text { technology }\end{array}$ & Varieties & Year & Yield & Protein & Gluten \\
\hline \multirow{9}{*}{$\mathrm{T} 1-$ basic } & \multirow{3}{*}{ Moscovskaya 40 variety (V1) } & 2017 & $9.5 \pm 0.23^{b}$ & $14.1 \pm 0.05^{\mathrm{c}}$ & $30.4 \pm 0.11^{\mathrm{c}}$ \\
\hline & & 2018 & $5.2 \pm 0.05^{\mathrm{d}}$ & $16.4 \pm 0.05^{\mathrm{b}}$ & $32.8 \pm 0.08^{\mathrm{b}}$ \\
\hline & & 2019 & $7.8 \pm 0.20^{\mathrm{bc}}$ & $16.1 \pm 0.05^{\mathrm{b}}$ & $32.2 \pm 0.10^{\mathrm{b}}$ \\
\hline & \multirow{3}{*}{ Nemchinovskaya 17 variety (V2) } & 2017 & $9.7 \pm 0.11^{\mathrm{ab}}$ & $14.2 \pm 0.11^{\mathrm{c}}$ & $28.3 \pm 0.15^{\mathrm{c}}$ \\
\hline & & 2018 & $6.4 \pm 0.05^{\mathrm{c}}$ & $14.5 \pm 0.05^{\mathrm{c}}$ & $29.1 \pm 0.11^{\mathrm{c}}$ \\
\hline & & 2019 & $7.4 \pm 0.03^{\mathrm{c}}$ & $16.9 \pm 0.11^{\mathrm{b}}$ & $33.8 \pm 0.10^{\mathrm{c}}$ \\
\hline & \multirow{3}{*}{ Nemchinovskaya 85 variety (V3) } & 2017 & $9.9 \pm 0.28^{b}$ & $14.8 \pm 0.05^{\mathrm{c}}$ & $31.2 \pm 0.05^{\mathrm{c}}$ \\
\hline & & 2018 & $7.1 \pm 0.06^{\mathrm{c}}$ & $15.1 \pm 0.05^{\mathrm{c}}$ & $30.2 \pm 0.10^{\mathrm{c}}$ \\
\hline & & 2019 & $7.4 \pm 0.03^{\mathrm{c}}$ & $17.6 \pm 0.11^{\mathrm{b}}$ & $35.2 \pm 0.15^{\mathrm{ab}}$ \\
\hline \multirow{9}{*}{$\mathrm{T} 2$ - intensive } & \multirow{3}{*}{ Moscovskaya 40 variety (V1) } & 2017 & $10.5 \pm 0.24^{\mathrm{ab}}$ & $15.4 \pm 0.05^{\mathrm{b}}$ & $31.5 \pm 0.05^{\mathrm{c}}$ \\
\hline & & 2018 & $8.4 \pm 0.11^{\mathrm{b}}$ & $17.7 \pm 0.05^{\mathrm{b}}$ & $36.7 \pm 0.15^{\mathrm{ab}}$ \\
\hline & & 2019 & $8.2 \pm 0.10^{\mathrm{b}}$ & $19.1 \pm 0.05^{\mathrm{ab}}$ & $38.2 \pm 0.15^{\mathrm{a}}$ \\
\hline & \multirow{3}{*}{ Nemchinovskaya 17 variety (V2) } & 2017 & $10.4 \pm 0.23^{\mathrm{ab}}$ & $15.6 \pm 0.10^{\mathrm{b}}$ & $33.2 \pm 0.08^{\mathrm{b}}$ \\
\hline & & 2018 & $7.1 \pm 0.14^{\mathrm{c}}$ & $16.1 \pm 0.05^{\mathrm{b}}$ & $32.2 \pm 0.15^{\mathrm{b}}$ \\
\hline & & 2019 & $7.9 \pm 0.11^{\mathrm{bc}}$ & $17.8 \pm 0.11^{\mathrm{b}}$ & $37.6 \pm 0.15^{\mathrm{a}}$ \\
\hline & \multirow{3}{*}{ Nemchinovskaya 85 variety (V3) } & 2017 & $13.1 \pm 0.17^{\mathrm{a}}$ & $15.6 \pm 0.05^{\mathrm{b}}$ & $32.5 \pm 0.05^{\mathrm{b}}$ \\
\hline & & 2018 & $7.3 \pm 0.05^{\mathrm{c}}$ & $16.4 \pm 0.05^{\mathrm{b}}$ & $32.8 \pm 0.10^{\mathrm{b}}$ \\
\hline & & 2019 & $8.3 \pm 0.05^{\mathrm{b}}$ & $18.9 \pm 0.11^{\mathrm{ab}}$ & $37.2 \pm 0.15^{\mathrm{a}}$ \\
\hline \multirow{9}{*}{$\begin{array}{l}\mathrm{T} 3-\text { high } \\
\text { intensive }\end{array}$} & \multirow{3}{*}{ Moscovskaya 40 variety (V1) } & 2017 & $14.1 \pm 0.17^{\mathrm{ab}}$ & $15.5 \pm 0.05$ & $33.4 \pm 0.20^{\mathrm{b}}$ \\
\hline & & 2018 & $9.03 \pm 0.17^{\mathrm{b}}$ & $18.3 \pm 0.05^{\mathrm{ab}}$ & $36.6 \pm 0.10^{\mathrm{ab}}$ \\
\hline & & 2019 & $8.7 \pm 0.1^{\mathrm{b}}$ & $19.6 \pm 0.11^{\mathrm{a}}$ & $39.2 \pm 0.10^{\mathrm{a}}$ \\
\hline & \multirow{3}{*}{ Nemchinovskaya 17 variety (V2) } & 2017 & $13.3 \pm 0.17^{\mathrm{a}}$ & $16.8 \pm 0.05^{\mathrm{b}}$ & $35.1 \pm 0.05^{\mathrm{ab}}$ \\
\hline & & 2018 & $8.2 \pm 0.11^{\mathrm{b}}$ & $16.9 \pm 0.17^{\mathrm{b}}$ & $33.4 \pm 0.08^{\mathrm{b}}$ \\
\hline & & 2019 & $8.03 \pm 0.14^{\mathrm{a}}$ & $18.9 \pm 0.05^{\mathrm{ab}}$ & $39.8 \pm 0.05^{\mathrm{a}}$ \\
\hline & \multirow{3}{*}{ Nemchinovskaya 85 variety (V3) } & 2017 & $13.3 \pm 0.16^{\mathrm{a}}$ & $16.5 \pm 0.05^{\mathrm{b}}$ & $33.9 \pm 0.10^{\mathrm{b}}$ \\
\hline & & 2018 & $7.6 \pm 0.11 b^{c}$ & $16.8 \pm 0.05^{\mathrm{b}}$ & $33.6 \pm 0.10^{\mathrm{b}}$ \\
\hline & & 2019 & $8.7 \pm 0.05^{b}$ & $19.4 \pm 0.11^{\mathrm{ab}}$ & $39.8 \pm 0.05^{\mathrm{a}}$ \\
\hline \multirow{7}{*}{$p$-value } & Cultivation technology & & $\leq 0.002$ & $\leq 0.002$ & $\leq 0.002$ \\
\hline & Variety & & $\leq 0.003$ & $\leq 0.002$ & $\leq 0.003$ \\
\hline & Year & & $\leq 0.002$ & $\leq 0.004$ & $\leq 0.002$ \\
\hline & Cultivation technology $\times$ Variety & & $\leq 0.002$ & $\leq 0.003$ & $\leq 0.005$ \\
\hline & Cultivation technology $\times$ Year & & $\leq 0.006$ & $\leq 0.005$ & $\leq 0.004$ \\
\hline & Variety $\times$ Year & & $\leq 0.003$ & $\leq 0.007$ & $\leq 0.006$ \\
\hline & Cultivation technology $\times$ Variety $\times$ Year & & $\leq 0.004$ & $\leq 0.005$ & $\leq 0.008$ \\
\hline
\end{tabular}

Values represent the average of 3 replicates \pm SE (standard errors), $p$-values from ANOVA (cultivation technology, variety, year, cultivation technology $\times$ variety, cultivation technology $\times$ year, variety $\times$ year and cultivation technology $\times$ variety $\times$ year).

Different letters in column indicate significant difference between means and they were determined by Tukey test 
value was observed for all three species. High intensive cultivation technology T3 determined as the most effective treatment in weed control, attaining 0.3 plant $/ \mathrm{m}^{2}$ Echinochloa crus-galli, $0.5 \mathrm{plant} / \mathrm{m}^{2}$ Stellaria media and $0.4 \mathrm{plant} / \mathrm{m}^{2}$ in Viola arvensis. Cultivation technologies 1 and 2 also showed high efficacy in reducing weed densities, since the weed control was ranged $75-80 \%$ and $85-93 \%$, respectively.

Figure 2 exhibits the effects of the three applied cultivation technologies during the study (2017,
2018, and 2019). Cultivation technology (T3, high intensive) was the most effective in controlling weeds during the trial, since the weed density decreased over the years as shown by the following values 0.6 plant $/ \mathrm{m}^{2} \pm 0.02,0.3$ plant $/ \mathrm{m}^{2} \pm 0.02$, and 0.2 plant $/ \mathrm{m}^{2} \pm 0.01$ in 2017,2018 and 2019 , respectively.

The biological efficiency of the investigated cultivation technologies is shown in Figure 3. The highest biological efficiency was obtained when cultivation technologies 2 and 3 were used with

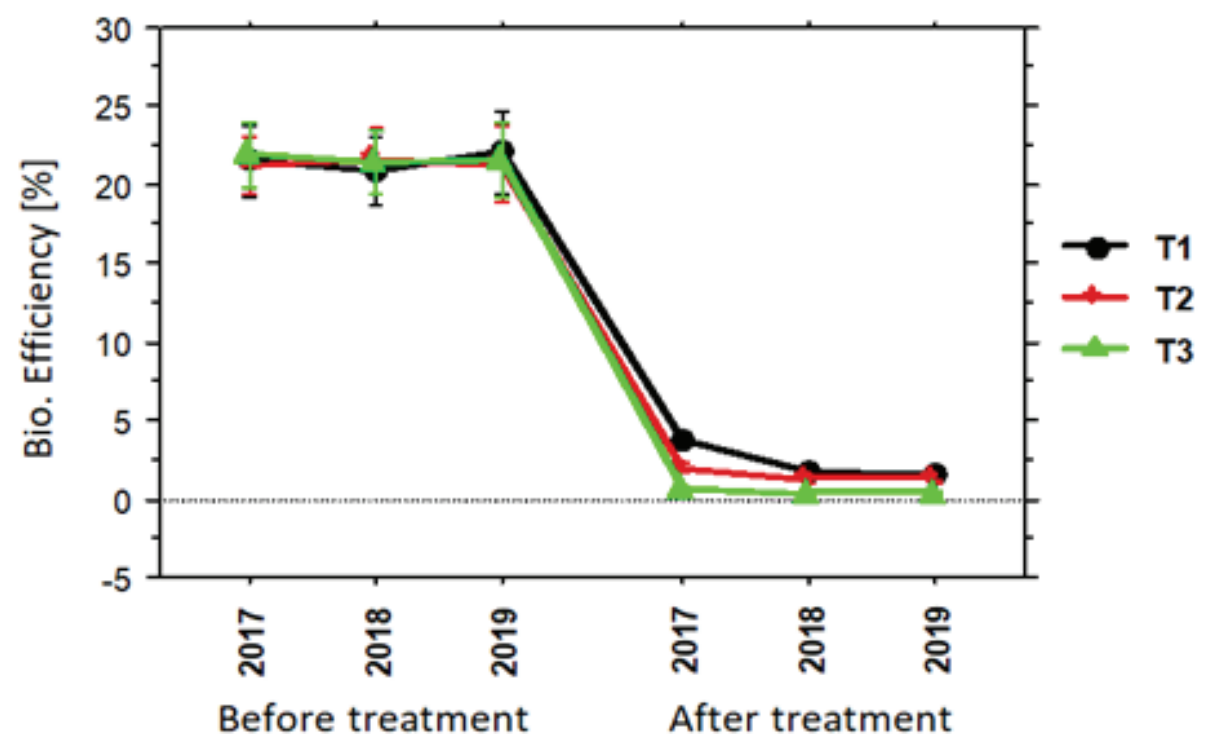

Figure 2. Effect of the three cultivation technologies (T1 - basic, T2 - intensive and T3 - high intensive) on biological efficiency during the study period (2017, 2018 and 2019)

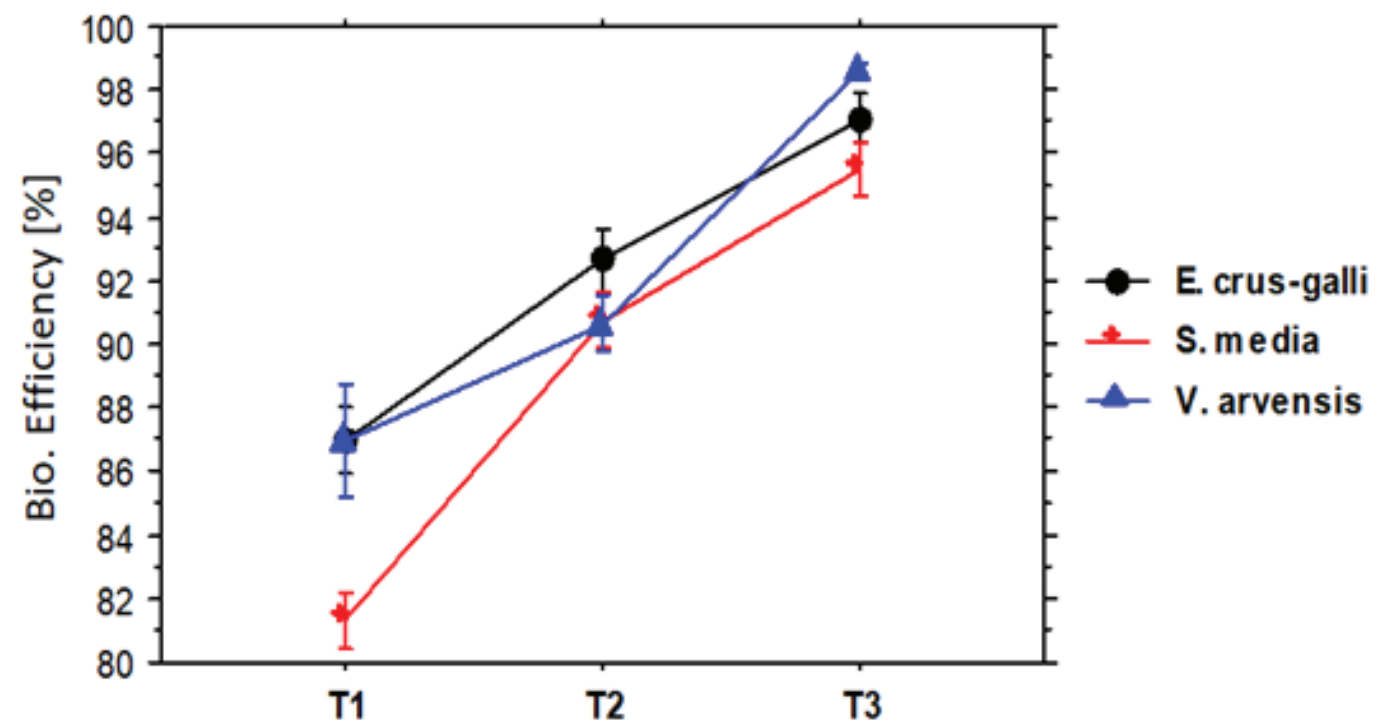

Figure 3. The biological efficiency of the investigated cultivation technologies to control weed (T1 - basic, T2 - intensive and T3 - high intensive) 
$90 \%$ and $96 \%$, respectively. The cultivation technology 1 also seems to be effective in suppressing weeds, since 87,81 , and $88 \%$ weed biomass was reduced in Echinochloa crus-galli, Stellaria media, and Viola arvensis, respectively.

\section{Yield performance and grain quality}

Figure 4 displays yield performances of the three winter wheat varieties attributed to the cultivation technologies. High intensive cultivation technology
(T3) gave the best yields whatever the considered wheat variety. It is noted that there was no significant difference in the yield potential of all studied varieties. Moscovskaya 40 variety (V1), Nemchinovskaya 17 variety (V2) and Nemchinovskaya 85 variety (V3) yielded $10.6 \pm 0.14 \mathrm{t} / \mathrm{ha}, 9.8 \pm 0.39$ $\mathrm{t} / \mathrm{ha}$ and $9.9 \pm 0.21 \mathrm{t} / \mathrm{ha}$ respectively throughout the study. On the other hand, the lowest yield was recorded when the basic cultivation technology was

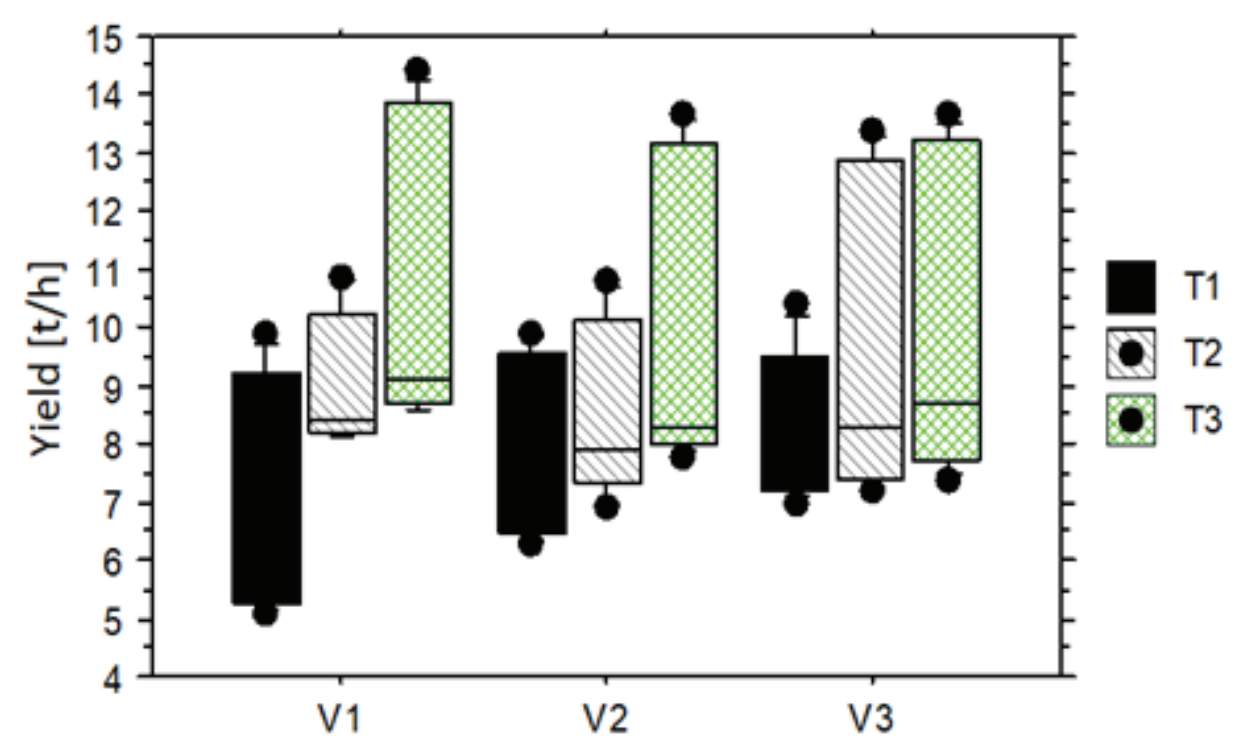

Figure 4. Yield performances of the three studied winter wheat varieties (Moscovskaya 40 variety (V1), Nemchinovskaya 17 variety (V2), and Nemchinovskaya 85 variety (V3)) as influenced by the cultivation technologies (T1 - basic, T2 - intensive and T3 - high intensive)

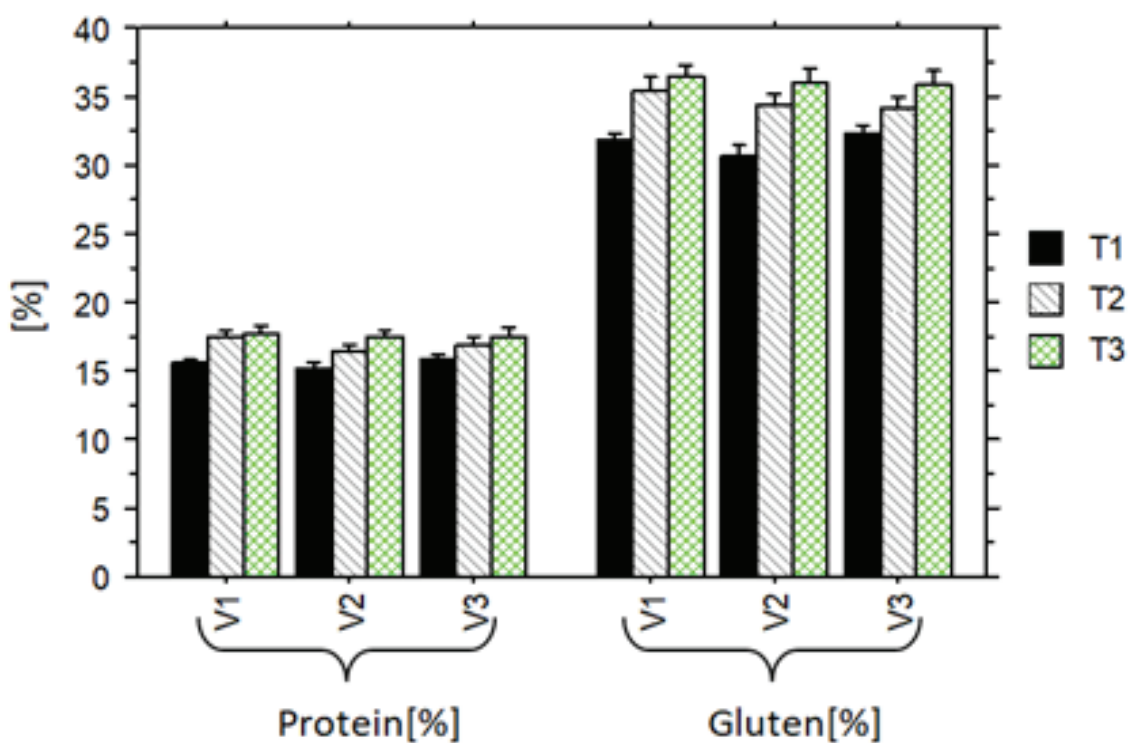

Figure 5. Protein and gluten contents of the three studied winter wheat varieties (Moscovskaya 40 variety (V1), Nemchinovskaya 17 variety (V2), and Nemchinovskaya 85 variety (V3)) attributed to the cultivation technologies (T1 - basic, T2 - intensive and T3 - high intensive) 
implemented (T1) in all wheat varieties $7.5 \pm 0.45$ (V1), $7.8 \pm 0.29$ (V2) and $8.1 \pm 0.27 \mathrm{t} / \mathrm{ha}$ (V3).

Grain quality was analysed based on protein and gluten contents in the different wheat varieties. The results showed that the protein and gluten content increased significantly by intensity of cultivation technologies (Figure 5). The highest protein and gluten content were observed when the high intensive cultivation technology was performed (T3) for all tested varieties in the values $17.8 \% \pm 0.30$ (V1), $17.5 \% \pm 0.32(\mathrm{~V} 2)$ and $17.6 \% \pm 0.42(\mathrm{~V} 3)$ for protein content and $36.4 \% \pm 0.90$ (V1), 36.1\% \pm 0.59 (V2) and $36.7 \% \pm 0.63(\mathrm{~V} 3)$ for gluten content.

In Table 2, the analysis of variance for grain yield and quality (protein and gluten content) revealed that the cultivation technology, variety, and year had a highly significant effect on the yield and grain quality $(p \leq 0.05)$. In addition, the yield and grain quality were significantly affected by the interaction between all studied treatments (cultivation technology $\times$ variety, cultivation technology $\times$ year, variety $\times$ year, and cultivation technology $\times$ variety $\times$ year $)(p \leq 0.05)$.
Figure 6 shows the relationship between biological efficiency of treatments, wheat yield, and grain quality by using linear regression. The biological efficiency of cultivation technologies is not correlated with grain yield $\mathrm{r}^{2}=0.05$, however protein and gluten contents enhance with increasing biological efficiency of treatments $r^{2}=0.50$ and $r^{2}=0.52$, respectively.

\section{DISCUSSION}

Weeds are a serious challenge in wheat production. They generate colossal yield losses through the competition for nutrients with crops. An effective weed management system in modern agriculture is indispensable for the achievement of high grain yield. Here we demonstrate the practicability of varied levels of cultivation technologies in enhancing crop competitive ability against the weeds, hence, minimizing crop losses and simultaneously augmenting grain quality. Precursory studies evaluating the effect of herbicides and fertilisers in controlling
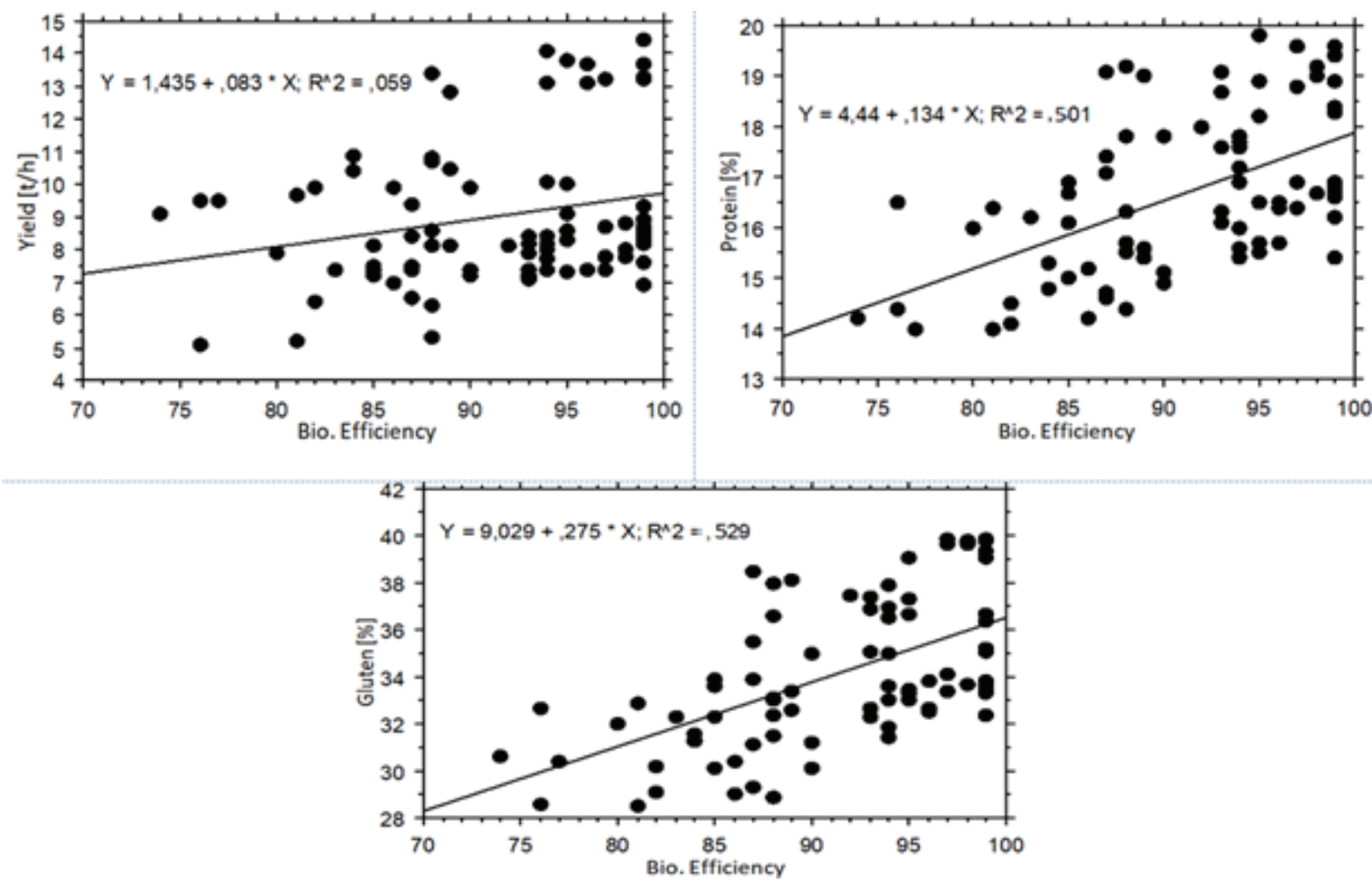

Figure 6. The relationship between biological efficiency of cultivation technologies, wheat grain yield, protein and gluten contents 
weeds have illustrated that compliance with the doses of inputs and timely application improve wheat yield and grain quality (Latati et al. 2019; Rebouh et al. 2019).

Herbicides have become one of the most used methods for weed control. The present study was designed to determine the effect of three cultivation technologies, which also embraced the use of herbicides to control weeds in the winter wheat crop. The results showed that the studied cultivation technologies had favorable biological efficiency to control Echinochloa crus-galli, Stellaria media and Viola arvensis. The high intensive cultivation technology was the most effective among all experimental treatments, since 87,81 and $88 \%$ efficiency was obtained for Echinochloa crus-galli, Stellaria media and Viola arvensis suppression, respectively. This was likely due to the presence of florasulam and tribenuron-methyl belonging to triazolopyrimidine class, which impedes the biosynthesis of branchedchain amino acids (leucine, isoleucine and valine) by inhibiting the enzyme ALS also known as AHAS (Weis et al. 2008).

Baghestani et al. (2007) and Zand et al. (2010) reported that florasulam and tribenuron-methyl were very effective for the management of Echinochloa crus-galli, Stellaria media and Viola arvensis, their findings are in agreement with those reported in the current study. High intensive cultivation technology including florasulam and tribenuron-methyl (Tandem), belonging to triazolopyrimidine, significantly reduced weed density 1.8 plant $/ \mathrm{m}^{2}, 1.9$ plant $/ \mathrm{m}^{2}$ and $1.2 \mathrm{plant} / \mathrm{m}^{2}$ for Echinochloa crus-galli, Stellaria media and Viola arvensis, respectively.

Murphy and Lemerle (2006) have shown that the type and rate of fertilisers used play an important role in weed population shifts and an inappropriate dose of fertilisers significantly affects the abundance of weeds in crops. For example, the number of weed individuals decreases and their biomass increases with enhancing nitrogen fertiliser levels (Mahn et al. 1988; Tang et al. 2014).

In the current study, the implemented fertiliser rates $\left[\mathrm{N}(60-150), \mathrm{P}_{2} \mathrm{O}_{5}(30-90), \mathrm{K}_{2} \mathrm{O}(90-150)\right]$ were balanced which promoted wheat crop growth, resulting in closed crop stands and limited light for weed communities. In addition, winter wheats (Moskovskaya 40, Nemchinovskaya 17 and Nem- chinovskaya 85) seem to have the high competitive ability, which resulted in reduced weed pressure and diffusion in the cropping system. These results corroborate the findings of a great deal of the previous works, which demonstrated the importance of the competitive ability of the cultivated genotypes in weed management (Bastiaans et al. 2008; Andrew et al. 2015).

Weed resistance to herbicides is increasingly becoming problematic in crop production systems across the globe. The repeated use of herbicides with the same mode of action ultimately leads to the rapid spread of the resistant genotypes in the weed population (Heap et al. 2018; Nakka et al. 2019). The established spatio-temporal analysis to study the effect of cultivation technologies on weed species abundance carried out over three years of trials (Figure 2) showed that the investigated cultivation technologies reduced weeds infestation levels over the years. This is probably due to the combined effect of crop rotation and tillage before the sowing season, which optimized the efficacy of herbicides in weed control. These results were in consistent with the findings reported by Mishra and Singh (2012), whereby tillage followed by herbicide application increased biological efficiency and reduced the chances of the weeds developing resistance to applied herbicides. Messaoudi et al. (2020) and MacLaren et al. (2021) also noticed that the combined tillage-crop rotation provides better weed control results than tillage-monoculture combination, which leads us to conclude that weed management depends on several factors that constitute cultivation technology such as herbicide, crop rotation, tillage, fertilisation, genetic characteristics of cultivars and others.

Previous studies demonstrated that herbicide use generally does not affect wheat yields, but increases grain quality of crops (Storkey et al. 2003; Benjamin et al. 2010; Gaba et al. 2016). This study was premised on assessing the efficacy of the herbicides both in weed control and enhancement of wheat yield and the grain quality. The analyses of the relationship between biological efficiency of treatments, wheat yield and grain quality by using the linear regression did not show any relationship between wheat yields and herbicide use $\left(r^{2}=0.05\right)$, however, there is a moderately positive relationship 
between protein, gluten content, and biological efficiency of herbicide $r^{2}=0.50, r^{2}=0.52$, respectively (Figure 6). This is probably due to the competitive ability of the cultivated genotypes, which increases their nutrient uptake rate, thus improving grain quality (Van der Meulen et al. 2017; Polityko et al. 2020). Moreover, our findings from the previous study where we explored the nutrient use efficiency of the winter wheat cultivars investigated in the current work exhibited that Moskovskaya 40, Nemchinovskaya 17 and Nemchinovskaya 85 had high nutrient uptake capacity (Rebukh et al. 2019).

\section{CONCLUSIONS}

Weeds are one of the major constraints in crop yields and quality, causing huge economic losses. The present study showed that the weed management systems by the using several factors including fertilisers and growth regulators, at indicated rates, offered optimal weed reduction (96\%) and increased grain yield by $3 \mathrm{t} / \mathrm{ha}$. Moskovskaya 40, Nemchinovka 17 and Nemchinovka 85 expressed high competitive ability. Thus, the obtained results in our study indicated that balanced fertilisation and rational use of herbicides could be used as an effective method to suppress weeds, which allows not only maintenance of a stable crop yield but also greatly reduce weed reproduction. The current results open real opportunities for large-scale performing the cultivation technologies in different regions of Russia and exhibited new varieties that could offer high performance and weed-crop competitive ability.

Acknowledgements: This paper has been supported by the RUDN University Strategic Academic Leadership Program.

Conflicts of Interest: The authors declare no conflict of interest.

\section{REFERENCES}

Andrew, I.K.S., Storkey, J. and Sparkes, D.L. (2015). A review of the potential for competitive cereal cultivars as a tool in integrated weed management. Weed Research, 55, 239-248. DOI:10.1111/wre.12137.

Baghestani, M.A., Zand, E., Soufizadeh, S., Bagherani, N. and
Deihimfard, R. (2007). Weed control and wheat (Triticum aestivum L.) yield under application of 2,4-D plus carfentrazone-ethyl and florasulam plus flumetsulam: Evaluation of the efficacy. Crop Protection, 26(12), 1759-1764. DOI:10.1016/j.cropro.2007.03.007.

Bastiaans, L., Paolini, R. and Baumann, D.T. (2008). Focus on ecological weed management: What is hindering adoption? Weed Research, 48(6), 481-491. DOI:10.1111/j.13653180.2008.00662.x

Beckie, H.J., Heap, I.M., Smeda, R.J. and Hall, L.M. (2000). Screening for herbicide resistance in weeds 1 . Weed Technology, 14(2), 428-445. DOI:10.1614/0890-03 7X(2000)014[0428:SFHRIW]2.0.CO;2.

Benjamin, L.R., Milne, A.E., Parsons, D.J. and Lutman, P.J.W. (2010). A model to simulate yield losses in winter wheat caused by weeds, for use in a weed management decision support system. Crop Protection, 29(11), 1264-1273. DOI:10.1016/j.cropro.2010.07.015.

Chhokar, R.S., Sharma, R.K. and Sharma, I. (2012). Weed management strategies in wheat-A review. Journal of Wheat Research [online], 4(2), 1-21. Available at: https://sawbar.in/ wp-content/uploads/2018/07/Weed-managment-stratergiesin-wheat-A-review.pdf [Accessed 22 Sep. 2020].

De Vita, P., Colecchia, S.A., Pecorella, I. and Saia, S. (2017). Reduced inter-row distance improves yield and competition against weeds in a semi-dwarf durum wheat variety. European Journal of Agronomy, 85, 69-77. DOI:10.1016/j. eja.2017.02.003.

Fahad, S., Hussain, S., Chauhan, B.S., Saud, S., Wu, C., Hassan, S. and Huang, J. (2015). Weed growth and crop yield loss in wheat as influenced by row spacing and weed emergence times. Crop Protection, 71, 101-108. DOI:10.1016/j.cropro.2015.02.005.

Fragasso, M., Iannucci, A. and Papa, R. (2013). Durum wheat and allelopathy: Toward wheat breeding for natural weed management. Frontiers in Plant Science, 4, Article 375. DOI: $10.3389 /$ fpls.2013.00375.

Gaba, S., Gabriel, E., Chadœuf, J., Bonneu, F. and Bretagnolle, V. (2016). Herbicides do not ensure for higher wheat yield, but eliminate rare plant species. Scientific Reports, 6(1), 30112. DOI:10.1038/srep30112.

Gharde, Y., Singh, P. K., Dubey, R.P. and Gupta, P.K. (2018). Assessment of yield and economic losses in agriculture due to weeds in India. Crop Protection, 107, 12-18. DOI:10.1016/j.cropro.2018.01.007.

Heap, I. M. (2018). International Survey of Herbicide Resistant Weeds [Online]. Available at: www.weedscience.org.

Hosseini, P., Karimi, H., Babaei, S., Mashhadi, H.R. and Oveisi, M. (2014). Weed seed bank as affected by crop rotation and disturbance. Crop Protection, 64, 1-6. DOI:10.1016/j. cropro.2014.05.022.

Ibrahim, H., Pansu, M., Blavet, D., Hatira, A., Mcdonald, P., Bernoux, M. and Drevon, J.J. (2016). Modelling the continuous exchange of carbon between living organisms, the soil and the atmosphere. Plant and Soil, 398(1-2), 381-397. DOI:10.1007/s11104-015-2665-4.

Kjeldahl, J. (1883). A new method for the determination of nitrogen in organic matter. Zeitschrift für Analytische Chemie, 22, 366-382. DOI:10.1007/BF01338151.

Latati, M., Dokukin, P., Aouiche, A., Rebouh, N.Y., Takouachet, R., Hafnaoui, E. and Ounane, S.M. (2019). Species interactions improve above-ground biomass and land use efficiency in intercropped wheat and chickpea under low soil inputs. Agronomy, 9(11), 765. DOI:10.3390/agronomy9110765.

Maclaren, C.V., Labuschagne, J. and Swanepoel, P.A. (2021). Tillage practices affect weeds differently in monoculture vs. crop rotation. Soil and Tillage Research, 205, 104795. 
DOI:10.1016/j.still.2020.104795.

Mahn, E.G. (1988). Changes in the structure of weed communities affected by agro-chemicals: what role does nitrogen play? In Eijsackers, H. and Quispel, A. (Eds.) In the series analytic: Ecological implications of contemporary agriculture: Proceedings of a Symposium, held Sept 7-12, Wageningen, Netherlands. Available at: https://www.jstor.org/ stable/20112994 [Accessed 2 Fev. 2020].

Mason, H ., Navabi, A., Frick, B., O’Donovan, J. and Spaner, D. (2007). Cultivar and seeding rate effects on the competitive ability of spring cereals grown under organic production in Northern Canada. Agronomy Journal, 99(5), 1199-1207. DOI:10.2134/agronj2006.0262.

Messaoudi, H., Gérard, F., Dokukin, P., Djamai, H., Rebouh, Y.N. and Latati, M. (2020). Effects of intercropping on field-scale phosphorus acquisition processes in a calcareous soil. Plant and Soil, 449, 331-341. DOI:10.1007/s11104020-04491-7.

Mishra, J.S. and Singh, V.P. (2012). Tillage and weed control effects on productivity of a dry seeded rice-wheat system on a Vertisol in Central India. Soil and Tillage Research, 123, 11-20. DOI:10.1016/J.STILL.2012.02.003.

Murphy, C.E. and Lemerle, D. (2006). Continuous cropping systems and weed selection. Euphytica, 148, 61-73. DOI: 10.1007/s10681-006-5941-9.

Nakka, S., Jugulam, M., Peterson, D. and Asif, M. (2019). Herbicide resistance: Development of wheat production systems and current status of resistant weeds in wheat cropping systems. The Crop Journal, 7(6), 750-760. DOI:10.1016/j. cj.2019.09.004.

Nazarko, O.M., Van Acker, R.C. and Entz, M.H. (2005). Strategies and tactics for herbicide use reduction in field crops in Canada: A review. Canadian Journal of Plant Science, 85(2), 457-479. DOI:10.4141/P04-158.

Nichols, V., Verhulst, N., Cox, R. and Govaerts, B. (2015). Weed dynamics and conservation agriculture principles: A review. Field Crops Research, 183, 56-68. DOI:10.1016/j. fcr.2015.07.012.

Pansu, M., Ibrahim, H., Hatira, A., Brahim, N., Drevon, J.J., Harmand, J.M. and Blavet, D. (2018). Modelling the continuous exchange of nitrogen between microbial decomposers, the organs and symbionts of plants, soil reserves and the atmosphere. Soil Biology and Biochemistry, 125, 185-196. DOI:10.1016/j.soilbio.2018.06.011 .

Polityko, P., Rebouh, N.Y., Kucher, D., Vvedenskiy, V., Kapranov, V., Atmachian, G. and Latati, M. (2020). Productivity and grain quality of three spring wheat (Triticum aestivum 1.) cultivars under three cultivation technologies. EurAsian Journal of BioSciences, 14(1), 2089-2095.
Rebouh, N.Y., Latati, M., Polityko, P., Kucher, D., Hezla, L., Norezzine, A. and Iguer-Ouada, M. (2020). Influence of three cultivation technologies to control Fusarium spp. in winter wheat (Triticum aestivum L.) production under Moscow conditions. Research on Crops, 21(1), 17-25. DOI: $10.31830 / 2348-7542.2020 .003$.

Rebouh, N.Y., Polityko, P.M., Pakina, E., Plushikov, V.G., Norezzine, A. , Gadzhikurbanov, A. and Iguer-Ouada, M. (2019). Impact of three integrated crop protection treatments on the varieties of winter wheat (Triticum aestivum L.) in Moscow area, Russia. Research on Crops, 20(1), 161-168. DOI:10.31830/2348-7542.2019.022.

Rebukh, N.Y., Polityko, P.M., Kapranov, V.N. and Kiselev, E.F. (2019). Nutrient removal and payback of mineral fertilizers by harvest of winter wheat varieties under technologies of different intensity levels. RUDN Journal of Agronomy and Animal Industries, 14(2), 142-153. DOI:10.22363/2312797X-2019-14-2-142-153.

Storkey, J., Cussans, J.W., Lutman, P.J.W. and Blair, A.M. (2003). The combination of a simulation and an empirical model of crop/weed competition to estimate yield loss from Alopecurus myosuroides in winter wheat. Field Crop Research, 84(3), 291-301. DOI:10.1016/S03784290(03)00096-0.

Tang, L., Cheng, C., Wan, K., Li, R., Wang, D., Tao, Y. and Chen, F. (2014). Impact of fertilizing pattern on the biodiversity of a weed community and wheat growth. PLoS ONE, 9(1): e84370. DOI:10.1371/journal.pone.0084370.

Mohammadi, H. and Ismail, B.S. (2018). Effect of herbicides on the density of broad leaf weeds and their effect on the growth and yield components of wheat (Triticum aestivum L.). Journal of Agronomy, 17(1), 11-17. DOI:10.3923/ ja.2018.11.17.

Weis, M., Gutjahr, C., Ayala, V.R., Gerhards, R., Ritter, C., Schölderle, F. Precision farming for weed management: techniques. Gesunde Pflanzen, 60(4), 171-181. DOI:10.1007/s10343-008-0195-1.

Van Der Meulen, A. and Chauhan, B.S. (2017). A review of weed management in wheat using crop competition. Crop Protection, 95, 38-44. DOI:10.1016/j.cropro.2016.08.004.

Vila-Aiub, M.M. (2019). Fitness of herbicide-resistant weeds: Current knowledge and implications for management. Plants, 8(11), 469. DOI:10.3390/plants8110469.

Talgre, L., Lauringson, E. and Koppel, M. (2008). Effect of reduced herbicide dosages on weed infestation in spring barley. Zemdirbyste, 95(3), 194-201.

Received: February 9, 2021 Accepted: May 27, 2021 